\title{
Economic Crimes: Factors Responsible For Rampant Fraud And Corruption In Kenya
}

\author{
Omboto, John Onyango \\ Lecturer Criminology and Security Studies \\ Egerton University-Department of Peace, Security and Social Studies
}

\begin{abstract}
On $28^{\text {th }}$ June, 2018 President Uhuru Kenyatta rightfully declared that there would be no sacred cows in the war against corruption in Kenya. This declaration came at a time when fraud and corruption is so common place to an extent that an occurrence is no longer news. In fact, as if competing for a trophy, every regime have had at least a mega scandal associated with it, thus continuously draining the treasury at the detriment of any meaningful economic growth and affordable cost of living for the citizens; majority of whom are destitute. Among the many outstanding scandals that have depleted billions of shillings from the tax payers associated with the three latest regimes are Goldenberg and Anglo leasing scandals, and the National Youth Service scams. This paper introduces the concept of fraud and corruption and discusses the types of corruption in Kenya, the red flags of fraud, mechanisms of controlling frauds and the factors that have over the years been responsible for the widespread corruption which has continued to plague the country.
\end{abstract}

Key words: Corruption, Fraud, Control mechanisms, Kenya

\section{INTRODUCTION}

According to Siegel,(1983) fraud involve misrepresentation of facts to cause a victim to willingly give his/her property to the wrongdoer who keeps it. It involves false pretences and differs from the normal theft because the victims are made to willing give their possession to the offenders after securing the confidence of property owners. Silverstone \& Sheetz,(2007) posit that fraud is an illegal act characterized by deceit, concealment or violation of trust and which are not dependent upon the application of threat of physical force or actual violence. Individuals and organizations commit frauds to obtain money, property or services. Some also seek to secure personal or business advantage. The victims of fraud can be an individuals, goverment and non-government entities.

The word fraud is at times interchanged with corruption. However, according to Oxford Advanced Learner's Dictionary, corruption is defined as dishonest or illegal behaviour, especially of individuals in authority. The corrupt are people who use their power or position to do dishonest or illegal things in return for money or to get an advantage. Corruption may involve bribery and inducements and is common in both the private and public sectors. It involves giving and receiving favours (Aldler.et.al, 1995). Other forms of corruption are misappropriation of resources and embezzelment. Siegel,(2006) posit that embezzelment occurs when a person trusted with public or organization property fradulently takes it for personal use. The property can be money or other movable or immovable assets. Thus, there are some similarity between fraud and corruption but a major difference between the two is that corruption involves a position of power or authority. 
In terms of typology, frauds are broadly categorized by the sector of the society where they occur or by the kind of the indviduals who commit them. Under the sector of the society, we have security related frauds which take place in the stock market, fraud against the government which are commonly perpertuated by government employees against their employer, and consumer frauds which involves tricking consumers to part with their money through deceit of material facts. Others are insurance frauds which are either committed by the insured persons and or next of kins or by the insurance companies. We also have frauds of the political class and the frauds within the medical sector which are commited by the medical personnel.

Against departments and organizations, frauds are committed by the employees, the management and outsiders thus we have employee frauds, management frauds and external fauds which are frauds committed by individuals who do not belong to the organization against which they commit the vice. The frauds commited by these outsiders include false representation, and thievery of documents, information and assets.

Frauds have severe consequenses to to the ecomomy, corporations and individuals (Silverstone \& Sheetz,2007). To a country, Manning,(2011) posit that international bussiness people prefer not to establish operations in a country where public officials are corrupt for fear of demand for pay offs and kick backs which will increase the cost of doing business. However organized criminals like drug barons find such countries the best places to conduct their illegal operations.

\section{Types of Corruption in Kenya}

According to ant-corruption campaigner John Githongo in a paper presentation titled 'The Culture of corruption in Kenya' there are three main types of frauds/corruption that occur in Kenya. These are petty corruption, grand corruption and looting (Khamisi, 2018). He opines that petty corruption are transacted between ordinary citizens and junior civil servants; the front line public employees. This type of corruption entails giving bribes to receive favours and services as is common when the public are dealing with the police, and other subordinate staffs in government offices.

He postulates that grand corruption is committed by senior government officials, and takes the form of kickbacks received to give government tenders, contracts and to recruit employees. On the other hand looting is the worst form of corruption. It is a hefty economic delinquency reflected in scams where the figures are so huge that they bring macro-economic consequences. These consequences include collapse of banks and industries, inflation, and fluctuation in foreign exchange rates among others. Whereas grand corruption involves inflation of costs of development projects, looting is committed through factoring of fictitious development projects in budget. While grand corruption is committed by senior government officers, looting is engineered by senior leading political players. It is common when the said high ranking political class feel threatened. Examples of lootings that have taken place in the country include Goldenberg scandal, Anglo leasing, and National Youth Service scams. The amounts always involved run into billions of shillings.

\section{The red flags of fraud, a commencement point in managing the vice}

The red flags of frauds are alarms or raised alerts that frauds may have been committed or are on- going. Red flags may vindicate individuals involved in frauds and pin point that all is not well in an organization or institution. These red flags include but not limited to public complaints of fraud, anonymous letters detailing fraud, rapid change of lifestyle in an employee, failure to taken holidays, and irrational or inconsistent behaviour. 
The public may complain of fraud in institutions or organizations where they are served. Such complaints may be about demand for bribes by the personnel. They may also complain when they are required to pay for services that should be offered for free. In most cases such complaints may be inform of public protests and demonstrations against the individuals involved and or the organization. The complaints may also take the form of anonymous letters detailing fraud by the corrupt individuals and their institutions.

Rapid change of lifestyle in employees which cannot be explained may also mean that they are corrupt and are involved in fraudulent activities. These are the symbolic indicators of corruption and fraud which may include driving big cars, living in maisonettes and generally living large beyond their means. Unless such individuals can explain their opulence to be through legal means then illegal means such as corruption would be the source. How for instance can an accounts clerk earning twenty thousand Kenya Shillings in a government ministry without any other legal income buy and maintain a top notch vehicle costing over ten million shillings?

Individuals who are engaged in corruption and fraud at their places of work will also not take holidays. This is because such people fear to leave their offices because the person who would be called to sit in may discover the cobwebs and skeletons of fraud in their closet. Thus in organizations there are individuals who do not take annual leaves for years. Another red flag of fraud is unusual, irrational or inconsistent behaviour by an employee or a manager. This may be refusing to give out documents for auditing, preferring particular auditor, claiming that some vital documents such as receipt books and cheque books have been misplaced, stolen or lost. Others are unusual office breakages, fire out breaks, losses of safe and or office keys among many others aimed at concealing frauds.

Though the presence of these red flags is not a fool proof indication of frauds and corruption, as a first line of action against the vice, it is vital to recognize and thoroughly investigate them. For instance, the public complaints of fraud and anonymous letters must not be ignored or wished away but thoroughly investigated and action where someone is culpable. Rapid change of lifestyle in an employee should similarly be investigated and proper lifestyle audit conducted on those working in places where corruption is rife. This easily gives away those involve in shoddy deals. Additionally, confiscation of ill gotten wealth by the state is a better measure to deter the offenders involved. Taking of annual leave by employees should be mandatory. The tendency by some workers to forfeit their leave days should not be tolerated. Further, all forms of irrational behaviour should raise alarm and instigate thorough investigations.

\section{Mechanisms for preventing frauds}

Manning,(2011) suggest various strategies for controlling frauds that target individuals and organizations. On frauds that target individuals he advices that peoople should be skeptical of agencies or persons who claim that they can assist through short cuts instead of legitimate procedures. He further advices that caution be taken on promises of of great financial reward at no risks, and never to allow oneself to be pushed into making quick decisions, and that incase of business engagements, to avoid making down payments of more than $25 \%$ of the total cost.

For organizations, the first strategy in preventing fraud is creation of awareness on fraud risks. This should begin with the management coming up with the common types of frauds and misconduct that may occur within their organization to warn the employees and all that deal with the entity. The awareness must also pass a strong message that all of the strategies 
established against fraud will be enforced including the punitive measures to the culprits. It should also provide information on the demerits of fraud to the organization and its perilous effect to the individual such as professional ruin and imprisonment among many others.

Most fraudulent activities that take place also involve outsiders to the institutions. It is therefore paramount to strictly control the third party transaction so as to curtail frauds that will involve these outsiders. These third parties may be either entities or individuals. For the individuals the frauds they get involved in include but not limited impersonation as employees and committing frauds and various crimes in the name of an organization. For instance, several people have masqueraded to be police officers and anti-corruption officials only to demand bribes. The third party entities whose activities also require strict monitoring are supplies who normally deal with the organizations, and whose activities may influence fraud within the institutions. In Kenya several frauds in government institutions have involved collusion between procurement officers and suppliers.

Similarly, related party transactions must also be put under tight control. These are activities of board members and top level employees or other employees of the organization who have interests in outside entities with which the organization conducts business. Such influential employees may authorize dishonest transactions that will benefit them at the detriment of their organization. For instance, an organizations' management may have links with supply firms, law firms, and auditing firms among others which they may use to overcharge or defraud their organization.

However, some frauds are mediated by poor financial reporting competency and integrity of the employees who work at the financial departments. It is worth noting that fraud is less likely to occur in an organization where highly competent persons in financial reporting oversight who are also of good character and integrity are in charge. These individuals must be experienced professionals chosen through an intensive interview and background checks thus are expected to be effective in preventing fraud at the financial department. To have a more comprehensive understanding of fraud, its red flags and potential to devastate the organization, institution and the country such professionals should be skilled in auditing, forensic accounting, and fraud management among other disciplines.

Alignment of authority and responsibility is also vital in fraud prevention. Fraud is less likely where an individual's authority is commensurate with his/her level of responsibility. A misalignment between authority and responsibility particularly in the absence of control mechanisms and segregation of duties can lead to fraud especially misappropriation of assets, bribery and theft. It is common to find people in organizations that are more powerful than their positions of employment - though this power is normally not formal. Such individuals may be relatives of powerful persons in government, or the managing director of the organization where they work. Others may be wives, husbands, brothers, sisters, girlfriends, boyfriends among others of the powerful people. These people normally misuse this 'power' of being well connected to solicit bribes from potential employees and suppliers, and to win dubious tenders among many other crimes they commit.

\section{The role of Human Resource Departments in fraud prevention}

The human resource section can play an important role in fraud prevention. This is done by ensuring that honest and competent employees are employed in an organization or government department. To begin with, human resource department should perform background investigation on potential employees before enlistment to prevent hiring individuals who have participated in dishonest or inapt behaviour in the past, or who exhibit 
behavioural propensities that imply a heightened risk of fraud. The department should also conduct background checks on existing employees who are candidates for promotion to positions in which they will handle or have assets and valuables to control. The checks assist to determine if someone has not been involved in illegal deals.

Likewise, background investigation should be extended to critical suppliers and customers to verify their character and financial reliability. The same should be applied to the business partners of the organization. Conducting antifraud training is another important function of human resource department. New employees who arrive at the organization should be trained to comply with the organization's code of conduct or ethics. Such training that includes antifraud programmes increases the likelihood that fraud will be prevented.

Finally, at times individuals are engaged in corruption and fraud as a survival mechanism. This is more so the case where the salary level is too low to support honest living. The prevention of these kinds of corruption and frauds by employees requires evaluating performance and compensation programmes by the human resource. This involves paying workers realistic salaries and wages that can support honest living based on the cost of living. It also requires rewarding best performers by promotion, and paid holidays among others.

\section{Why it has been impossible to eradicate fraud and corruption in Kenya}

Whereas fraud and corruption is a global problem and complete eradication may not be possible across jurisdictions, the following factors have made the two rampant in Kenya. First, frauds in Kenya are mostly committed by the elites and their cronies and relatives. These are the respected and powerful people in the society. They are top administrators in government such as departmental heads, cabinet secretaries, heads of corporations, the top politicians, and the business elites. For instance, the individuals who were mentioned in the three scandals: Goldenberg, Anglo leasing, and National Youth Service sleaze are not ordinary Kenyans, but individuals who belong to afore- mentioned categories.

Because of these criminals' high position in the society, they always frustrate the cases against them by destroying incriminating evidences, killing and or threatening the witnesses, which in the end make the cases to collapse in the courts of law. When this happens, the undeterred offenders continue with their fraudulent activities. Some of the cases of fraud and corruption are also instigated and or perpetuated by powerful multi-national companies. For example such multinationals are involved in price fixing in petroleum industry where they corrupt concerned regulators to set high prices that would earn them more profits at the detriment of the poor. These companies similarly always have powerful connections which they use to frustrate any fraud cases against them.

The law enforcement agents in Kenya are also handicapped in terms of qualifications and integrity to investigate and prosecute the cases that are of economic crimes in nature. For example, majority of the police who are the main government investigators do not have the professional skills to detect and investigate common corruption crimes such as financial misappropriations which need high qualifications in forensic accounting and audit because they are secondary school leavers thus are incapacitated. In terms of integrity, it has been observed that the police service in Kenya is most the corrupt government agency (Amnesty International, 2013), thus they are cheaply compromised and cannot be relied upon to conduct investigations on graft cases.

Lenient punishments by courts, lack of punishment at all or rulings that favour the corrupt have made fraud and corruption levels in Kenya worse. Lamenting that the courts frustrate the 
fight against graft, the former Kenya Anti Corruption Commission Director Prof. P.L.O. Lumumba told the media that he saw (in electronic media) a convict who swindled 6 million Kenya shillings leave the court smiling after being fined 1 million shillings (Omboto, (2013). Such lenient sentences to fraud culprits merely encourage them to continue with the crimes because it pays. The cardinal principle that should guide the punishment and treatment of offenders by the courts is that the punishment awarded must be parsimonious or commensurate with the severity of the crimes. Fraud and corruption cases in Kenya also do drag in courts of law for years before they are concluded. Normally, the suspects apply and receive favourable bail terms after which they frustrate the cases against them through constitutional injunctions and or constant adjournments on flimsy excuses. It is high time the government of the day took and supported legislations in parliament that outline the maximum duration of time a corruption case must be listened to and concluded by the courts. It is the opinion of this paper that a duration like three months will be enough if the courts are digitalized.

Failure to report frauds by the organizations that fall victims due to fear of bad publicity that may make them lose business is also a factor which has frustrated the fight against fraud and corruption in Kenya. Individuals who may have also been persuaded to participate in other acts of corruption such as giving bribes also in most cases do not report to the authorities when conned since they are complicit in the crimes. Some individual victims also view the police as more corrupt thus feel that they will be compelled to continue losing more in inducing them to act. Where cases are not reported thus not acted upon, the fraud levels remain high because the offenders will continue with similar crimes due to lack of deterrence.

Poor employee recruitment and promotion procedures are also responsible for high corruption rates in the country. In some organizations and government institutions individuals are employed based on negative 'isms' such as nepotism, god-fatherism, tribalism and clanism. Others earn their positions through acts of corruption and patronage thus in several organizations there are a pool of disobedient and dishonest workers who do not mind whether their corrupt practices bring down their institutions and the county. What seems to matter is gluttonous accumulation and conspicuous consumption of ill gotten wealth which they share with their higher up relatives and godfathers who placed them in those positions of plunder.

However, some corrupt lower cadre employees get into the vice for survival because of poor terms and conditions of work they are subjected to. Organizations that do not pay their workers wages that they can live on normally suffer higher levels of corrupt practises from such workers. For instance, poor terms of work is partly believed to be responsible for police corruption in Kenya (Amnesty International, 2013, Nyongesa, 2013, Mageka, 2015).

Finally, lack of role models in our society can also explain why fraud and corruption rates are high. The fact that news reports of political and religious leaders involved in all manner of scams is a constant feature in the print and electronic media leaves the ordinary Kenyan with no role model to emulate, yet according to Briggs, (1975), society members do not need leaders but role models to be law abiding.

\section{References}

Adler, F, Mueller. G.O \& Laufer W.S, (1995) Criminology $2^{\text {nd }}$ Ed. The Shorter Version McGraw Hill Company. New York, U.S.A.

Amnesty International, (2013) Police reforms in Kenya: "A drop in the Ocean" Amnesty International Publications London. 
Briggs, D. (1975) In Place of Prison - Towards a New Society. London: Maurice Temple Smith Ltd. Experts Second Edition- J. W \& Sons- USA.

Khamisi, J. (2018) Looters and Grabbers: 54 Years of Corruption and Plunder by the Elite, 1963-2017. Jodey Book Publishers-Plano, Texas USA.

Mageka, A. (2015) Police Reform in Kenya: Challenges and Opportunities. CSG. Insight No 9.

Manning. G.A. (2011) Financial Investigation and Forensic Accounting $3^{\text {rd }}$ Edition. CRC Press-Taylor and Francis Group-USA

Nyongesa, R.A (2013) Challenges of Strategy Implementation at Kenya Police Service. MBA

Omboto, J.O (2013) Poverty and Greed in Perspective on Crimes. International Journal of Research in Social Sciences Volume 2 No.4, pp.34-38.

Oxford Advanced Learner's Dictionary $6^{\text {th }}$ Edition-Oxford Press.

Siegel. L.J. (1983). Criminology $3^{\text {rd }}$ Edition. West publishing Company.

Siegel. L.J. (2006). Criminology $9^{\text {th }}$ Edition. West publishing Company.

Silverstone, H \& Sheetz, M (2007) Forensic Accounting and Fraud Investigation for Non- 